\title{
How to Teach Kindergarten Teacher Education Students about Play? The Perspective of Academic Pedagogy Teachers
}

\author{
Randi Moe \\ Western Norway University of Applied Sciences, Bergen, Norway
}

Copyright $(2019$ by authors, all rights reserved. Authors agree that this article remains permanently open access under the terms of the Creative Commons Attribution License 4.0 International License

\begin{abstract}
This paper applies a cultural-historical approach to researching the perspective of academic pedagogy teachers on good, campus-based teaching practices in the arena of play following the reform of Norwegian early childhood teacher education. The research material comprises over three world café conversations [1] with a total of 13 pedagogy teachers. The research material is analyzed using qualitative content analysis [2]. The results reveal pedagogy teachers' understandings of certain teaching practices like: a) professional conversations about play, b) play activities, and c) any other practices that facilitate students' critical reflection on play. Each of the points is supported by several crucial elements that make these practices good for teaching about play. Since the reconstructed teaching practices and elements that make them into "good practices" balance between theoretical and situated learning, the paper discusses conditions for situated cognition that are crucial when linking the subjectrelated theoretical content with the personal, real-life experiences of the students.
\end{abstract}

Keywords Kindergarten, Teacher Education, Norway, Teaching about Play, Norway, Professional Skills

\section{Introduction}

Play occupies a central role in the Nordic understanding and organization of childcare, and, thereby, also kindergarten teacher education. It has been shown to be an area of all-round development and children's participation. For various Norwegian academic and professional milieus, it was of a great importance to maintain the high position of play in kindergarten teacher education (KTE) under the reform in 2012. National follow-up research conducted on the first year of students completing the new KTE model revealed that the students were generally satisfied with the education received. The development of particular professional skills, including the ability to play and care and participatory interactions with children, scored as the most satisfying areas of KTE [3]. Although the majority was satisfied with the play-related subject and teaching practices, they also stated that play should have been given even greater focus in the campus-based and in-service teaching [4]. Since student experiences are not relegated to an institutional vacuum, but are dependent on teaching practices and available resources for them, this paper sheds light on academic pedagogy teachers and their perception of good practices connected with teaching play. The aim of this paper is to provide the academic teacher's perspective on best possible practices for teaching about play within the given resources so that student needs are met and the internationally recognized Nordic model being developed on children's terms of play is sustained.

\section{Cultural-historical Perspective of Teaching Practices in Kindergarten Teacher Education}

The theoretical toolkit used to describe and discuss institutional teaching and/or learning practices is the cultural-historical wholeness approach developed by Mariane Hedegaard [5]. The model relates conceptualizations of good childhood to cultural values on one hand, and institutional practices on the other. The institutional practices that are relevant in this case are those "practiced" by kindergartens, as well as those at teacher education institutions that are about students' learning about play.

This positions learning and knowledge as being constructed in a combination of social, historical, and cultural elements. Learning cannot be isolated from cultural terms [6]. Culture in this context means the form of practice and meanings that characterize an 
institutionalized or joint way of living [6: 8]. The institutionalized teaching practices at KTE are forms of practice (rooted in the Nordic perspective on childhoods) that condition student learning. Student learning foregoes at the campus as well as in-service institutional settings of ECE.

\subsection{The Societal Level: Culture and National Guidelines}

Nordic notions of good childhood and childcare are built on the cultural value of child-centeredness. According to this way of thinking, placing the child at the center of any kinds of reflections on and practices of childcare safeguards the goodness of childhood. The child-centeredness category, however, also encompasses value-based categories, as follows:

- naturalness and being close to nature;

- equality and egalitarianism;

- $\quad$ articipation and democracy defined as the lived daily experience of children;

- $\quad$ freedom conceptualized as the autonomy to play and to develop one's own self;

- emancipation or liberation from over-supervision and over-control by adults;

- warm and cooperative social relationships with adults and peers [7, 8];

- care, formative development, play, and learning processes are seen in context $[9,10]$.

The autonomy to play mentioned above and play in itself are also seen as arenas for safeguarding all aspects, including overall development. Overall development facilitated by child-initiated activities is also an important category in the national framework plans for kindergarten tasks and content $[11,12,13]$.

Embracing all the aspects of children's functioning and development (sensual, motional, emotional, social, intellectual, and spiritual) distinguishes the Nordic model from the Anglo-Saxon one that defines its quality through children's outputs and prioritizes intellectual development together with cognitive/academic skills $[14,15]$. That play is a great arena for focusing on children's participation is not of lesser importance $[16,17,18,19]$, and the temporary National Framework Plan for Kindergarten Content and Tasks [13] highlights the requirement as follows:

Kindergartens shall meet the children's need for play. Play shall be a key focus in kindergarten, and the inherent value of play shall be acknowledged. Kindergartens shall make good provision for play, friendship and the children's own culture. Play shall be an arena for the children's development and learning and for social and linguistic interaction. Kindergartens shall inspire and make room for different kinds of play both outdoors and indoors. Kindergartens shall help ensure that all children are able to experience happiness, humour, excitement and involvement through play - alone and together with others [13: 20].

\subsection{Institutional Practices: Kindergarten and Kindergarten Teacher Education}

This focus on play means that kindergartens are playbased and that children's free play occupies the majority of the day at these institutions [20]. This has consequences for KTE in that it has to be able to provide students with practices that develop motives and skills that encompass play. Knowledge about the requirements for play must be delivered through methods that enable the students to act as play professionals.

Knowledge about play is the greatest part of the area of knowledge referred to as child, development, play, and learning (Norwegian: Barns utvikling, lek og lcering $B U L L)$.

Within this area of knowledge, the phenomenon of play is described and discussed in the context of children's developmental needs, but also in the context of heterogeneous, diverse, and changing societies. This area of knowledge aims to provide students with the understanding and insight that are necessary for facilitating the play of children from different socio-cultural backgrounds and with various developmental needs. The aim is to support the all-round development of the individual and realize democratic values and participation. One of the most important skills to develop within this area of knowledge is observation and educational documentation that allow future teachers to document and reflect on their own practice in order to improve it in terms of play and learning processes in children's groups, peercommunities, participation, and inclusion.

With regard to methods of working, learning, teaching, and assessing, the National Guidelines for Kindergarten Teacher Education [13] underlines the responsibility of each university to provide students with diverse, tailored ways of working individually and collectively [13: 7]. Campus-based methods of working, teaching, and learning usually occur as lectures, workshops, mentoring, projectwork, and individual tasks. Exams and assignments are also conducted individually or collectively orally, in writing, or visually. Several assignments are linked to in-service periods, during which students work in kindergartens under the supervision of in-service teachers.

\subsection{Activity Settings - Conditions for Student Learning}

These various methods of teaching and learning can be referred to as activity settings since they facilitate and demand that certain motives and activities occur [6]. The most anticipated result of the activities performed is learning.

The cultural-historical perspective also distinguishes between theoretical and situated learning. Theoretical learning refers to traditional school learning in which 
teaching and learning activities are separate and prescribed to either the teacher, who knows and is teaching, or to the students, who do not know and are learning. Theoretical learning also refers also to subject-related matters that are isolated from the daily experience of the person who is learning [21].

Situated learning deconstructs this "didactic relationship" [22: 210] between the knowledgeable teacher and the students into "a richly diverse field of essential actors and, with it, other forms of relationships of participation" [23: $56]$, which is also referred to as a community of practice. This means that all participants can be resourceful and make contributions to the joint creation of knowledge. Moreover, situated learning abandons delivering subjectrelated matters outside of their natural social surroundings and is based on the assumption that certain skills can be learned where they are used authentically, e.g., like learning play with children, other students, and in-service teachers in kindergartens.

Nevertheless, in the academic context the knowledge accumulated by a person who knows is still important. There are certain books, articles, and theories that one has to become familiar with in order to become a professional, reflexive teacher who is able to contribute to group discussions, play with children, and discussions with other staff members. This means that in academic, campus-based contexts transfers of knowledge from so-called veterans to newcomers still occurs, at least during lectures or joint lectures. The cultural-historical concept that is useful in this activity settings is situated cognition. Although the process is about the transfer of subject-related matter, it can be done in a way that stimulates students' sense of agency in their own learning [24]. What is mentioned as important in stimulating students' sense of agency in their learning is referring subject-related matters to cultural practices, meeting the students as meaning-making subjects, providing possibilities for trying out subject-related matter in natural surroundings, and addressing the students' level of development [21, 25].

Achieving situated condition in campus-based teaching practices is optimal and complementary to the situated learning of play during in-service training periods. The present study aims to identify practices that are considered to be best teaching practices about and for play during campus-based teaching that facilitates achieving situated cognition.

\section{Methodology}

In order to answer the research question of what do academic pedagogy teachers perceive as good, campusbased teaching practices for the subject of play, 13 academic pedagogy teachers of KTE in Norway were interviewed. All of the informants were experienced pedagogy teachers working within the reformed KTE model. The interviews were organized as world café conversations that were similar to the informants' daily experience in the institution, and this is the same technique used for generating ideas during various teachers' meetings.

The world café method developed by Brown and Isacs[1] is used in various organizational settings connected with teaching, learning, and mentoring but also in workshops and seminars [26]. Practically seen, it is about gathering people around one table for a certain amount of time and leading their discussions by asking them questions that were prepared in advance. After they have answered one group of questions at one table, they move to another table where there is a new set of questions and/or points to discuss. In the context of this study, the world café was used as an interview-based, qualitative research method. The informants were used to this type of discussion, which is why it was used in the present study to gain access to their ways of understanding [27] and assessing the practice of teaching about play. This method is similar to focus interviews when the participants are encouraged not only to answer questions, but also discuss them among themselves, comment, and ask each other questions [28]. The group dynamics in this setting is important and can influence the data being generated, e.g., similarities and dissimilarities among the various qualities of perceiving phenomena can become more clear [29].

The group participating in the research. Each of the 13 academic pedagogy teachers participating in the study had at least four years each of experience teaching pedagogy, and they were all experienced in both the old and the new KTE models. Moreover, all of the teachers participating had professional knowledge on the subject of play and had taught it.

Conducting the research. The world café was conducted during a seminar for KTE pedagogy teachers at a university in Norway. Five tables were arranged in different rooms. A sheet of paper with questions and topics that the informants based their conversation on and writing implements were placed on each table. The 13 pedagogy teachers were divided into three groups of 4-5 participants each. The groups rotated according to a set plan that gave them 20 minutes at each table. Each of the tables was chaired and moderated by one researcher, who was also a pedagogy teacher. The author of this paper chaired the discussions on the subject of play. During the seminar, three discussions on play took place. All participant names were anonymized during transcript transcription. The first group consisted of informants with names beginning with the letter A (Alf, Aksel, Anders, Agnar, Arne), the second the letter B (Bjørn, Bernt, Brage, Bendic), and the third with the letter $\mathrm{C}$ (Casper, Cato, Christian, Christoffer).

Ethics. All the informants were informed about the goal of the study and the procedures for data storage, anonymization, and exploitation, and that their participation in the research was voluntary. The Norwegian Centre for Research Data stated that this research project 
does not deal with either personal or sensitive data, which led to the rapid approval of its non-conflict status in relation to general, national ethical guidelines

Nevertheless, the research interview is a social practice that invites the development of asymmetric power relationships between interviewer and informants [27]. In order to minimize my impact, I positioned myself as a listening moderator, but I must admit that I posed some follow-up questions here and there, which led the discussions back to the planned play-related track. This was taken naturally by the research participants, because we are colleagues in our daily professional lives. This means that I share the same theoretical perspectives that were mentioned during group discussions. It also means that I analyzed the data from the perspective of the involved standpoint of a pedagogy teacher who is politically and professionally involved in safeguarding the position of play in Norwegian KTE.

Qualitative Content Analysis. I decided to use a very systematic way of analyzing the research material. The choice was intended to help me to distance myself from the politically and professional involved position that I find myself when it comes to the role of play in early childhood education and kindergarten teacher education. While I am aware that there is no data analysis method that can guarantee objectivity, following a systematic way of analysis is seen as helpful in identifying and avoiding bias. The qualitative content analysis [2] that was used aims to systematically analyze open-ended texts by processing the empirical material using a category system. The main category used in this study was "teaching practices in play" that developed into the subcategories of "campus-based" and "in-service kindergarten-based." Further, the analysis continued to trace materials in the text that filled one or another subcategory [30]. As the focus of the study was to detect campus-based teaching practices developed by academic pedagogy teachers, I present only the part of results that refers to campus-based teaching. Academic pedagogy teachers have no direct insight into in-service kindergartens with regard to the ways students are taught about play or into their interactions with children and kindergarten staff. In other words, the results of the study embrace only academic pedagogy teachers' perceptions of the teaching practices developed by themselves on campus. The results of the analytical work are presented below.

\section{Findings}

The first distinction in teaching practices was related to campus-based and in-service kindergarten based practices. In the former subcategory, the following teaching practices were reconstructed. In the table below (Table 1), I also include elements that were essential to the informants if the practice was to be evaluated as good for students learning about play.

Table 1. Campus-based Teaching Practices Facilitating Learning about Play. Source: Author's Own Elaboration.

\begin{tabular}{|l|l|l|}
\hline \multirow{2}{*}{\begin{tabular}{|l|l|} 
Campus- Based Teaching \\
\begin{tabular}{|l} 
Practices Facilitating \\
learning about play
\end{tabular}
\end{tabular}} & $\begin{array}{l}\text { 1a) Students participating in } \\
\text { professional conversations about } \\
\text { play }\end{array}$ & $\begin{array}{l}\text { Wefers to one's own childhood experience } \\
\text { Links professional concepts to experiences } \\
\text { References to current debates on play }\end{array}$ \\
\cline { 2 - 3 } & 1b) Students participating in play & $\begin{array}{l}\text { Experiences outside of one's comfort zone } \\
\text { Letting control slide Joining in "as if" situations of role } \\
\text { play } \\
\text { Joining in laughter }\end{array}$ \\
\cline { 2 - 3 } & $\begin{array}{l}\text { 1c) Stimulating critical reflections } \\
\text { on play }\end{array}$ & $\begin{array}{l}\text { Environmental vulnerability of play } \\
\text { Play as an interdisciplinary phenomenon } \\
\text { Learning to play } \\
\text { Value of play } \\
\text { Idealization of play }\end{array}$ \\
\hline
\end{tabular}




\section{1a Students Participating in Professional Conversations about Play}

According to the group participating in the study, a professional conversation about play was objectively a good practice with which to teach students about play. However, certain elements were mentioned to safeguard the goodness of the practice in order to achieve learning goals. Thus, professional conversations about play were seen as good when they permitted and stimulated the students to:

- $\quad$ bring their own childhood experiences and reflect on them;

- $\quad$ link professional concepts with their own experiences;

- $\quad$ refer to current debates on the kindergarten sector and about play.

Bringing one's personal childhood experiences of play was of great importance at the beginning of KTE when the students were introduced to the broad subject of play and its position. Their own memories on play confirmed the importance of play. As one informant said:

I have good experience with first-year students in a play seminar where they begin to bring up good experiences with play from their own childhoods. They must tell each other about a game. What was happening? What is it that keeps this memory with you still? To me, this seems to be a good start to get the students on the path to reflecting on what play means to human beings (Aksel).

Linking professional concepts with real life experiences is another aspect that makes professional conversations about play a good teaching practice. This aspect of it is more important after the initial introduction of the subject matter. One way to connect theoretical concepts with reallife experiences of play is to provide the students with case studies or stories of real children. These are followed up with questions based on professional concepts.

I think it could be educational for the students to talk about specific play situations and analyze them with the help of theoretical concepts using either case studies about different play situations, their own written observations, or a practice story from the kindergarten. They should do this in groups and help each other with the analysis. Then they can develop a professional understanding of what play is (Agnar).

Referring to current debates was the last aspect of making professional conversations good. Not only was it mentioned that students should be updated on current kindergarten policy and thereby debates on play, but also that they should be enabled, as future kindergarten teachers, to be child advocates and political actors.

I try to challenge students by contextualizing the theoretical and practical in what is going on in society. Study plans are part of the social context, but I want to exceed topic plans and ask questions. What kinds of societies do we want? Why is play important in our time? What kind of debates are there going on? I want them to associate this with values, and I want the students to express meanings and have voices in these debates. (Anders).

\section{$1 \mathrm{~b}$ Students participating in play activities}

Another good campus-based teaching practice is to have students participate in play activities. For many, this experience is outside of their comfort zone, but their future professional lives will be full of these types of situations with children playing so the experience of it is necessary to ensure this teaching practice is a good one. Another important aspect is connected to letting control slide and allowing the flow of play and connections among people decide what is next. Connections with other people through laughter and humor and joint inter-subjectivity established in "as if" play are also important aspects that make this practice good. Briefly, experiencing play with one's own body and mind is what is necessary during this practice.

...to dare to let loose a little and to understand the game's essence. I think it's important to understand the meaning of play for children (Bjørn).

I think we should get the students to get down on the floor and do something in other roles and connect with each other in other roles (Bernt).

\section{1c Stimulating critical reflections on play}

Apart from the two practices mentioned, the informants insisted on including some necessary content that has to be transferred to the students in order to facilitate their critical reflection on play. In order to transfer this particular subject-related matter, no specific preferences about methods for this were mentioned, although both literature and lectures were mentioned. The content was of absolute importance so the students could be shown the complexity and diversity of play. This will facilitate their critical reflections in reference to the following issues.

Play's environmental vulnerability and its dependence on the physical milieu is important to mention as it is not included in sufficient quantities in the obligatory literature.

It seems to me that the significance of the impact of the physical environment on children's play should be emphasized more. We don't have much curriculum addressing this (Bernt).

Communicating that play as an interdisciplinary phenomenon and not only an unusual interest of pedagogues. Letting the students know that there are other disciplines interested in play will confirm the significance of play in childhood and childcare studies.

We have more in the academic milieus at the university that research on play and write about it. This should be 
communicated to the students (Casper).

Learning play is an adult-initiated learning activity that the children can turn into play. For example, the staff plans that the children will explore and experience water, but playing with it, as often happens in such situations, can also be a way to learn about gravity through play (Brage).

This aspect was also linked to the dichotomy between play and learning that one of the informants mentioned. (S)he suggested that KTE teachers should consciously stop using the distinction in interactions with students and when participating in public debate.

I think we still struggle with the play and learning dichotomy. I do not know how to do it, but I think it is necessary for us to get rid of it when we interact with students or when we engage in public debate.... (Bjørn).

The importance of the value of play demands that play not be treated instrumentally as a way of learning, but as a phenomena that has its own indisputable value in the experience of childhood regardless of the learning outputs.

At the same time we can't overlook the value of play. This is also reflected in many tasks the students write where they focus on the utility of play. Very often, they conclude what children learn through play instead of looking at the phenomenon of play, what meaning and importance this actually has for children. Being in play and experiencing what happens inside a child when she/he plays. When you forget about time and focus completely and only on the activity, then you are playing.... (Bernt).

On the other hand, the idealization of play may lead to over-romanticizing the phenomenon. Avoiding idealization can be achieved by providing the students with various theoretical perspectives on play that are both positive and critical of this phenomenon.

I think it is important to promote different views of play, to ensure the student has access to many theories of play and understandings of play. And that they can also be critical of these theories and the understandings themselves. I think that the more perspectives one has access to, the better the conditions are for facilitating play in kindergartens in relation to both the adult role and the play environment (Brage).

\section{The Subject of Play-Discussing Conditions for Situated Cognition}

The results above present teaching practices about play that are considered to be the best by academic pedagogy teachers providing campus-based teaching. In the theoretical part of the paper I described campus-based teaching as mostly dependent on the transfer of knowledge between veteran teachers and newcomer students. However, the possibility of situated cognition is based on students' own agency in developing their own knowledge in the context of knowledge transfer. Practices supporting student agency are about a) referring transmitted theoretical knowledge to cultural practices, b) facilitating student meaning-making processes, and c) addressing student levels of development. In other words, the conditions for situated condition are about meeting and supporting the students as subjects constructing their own knowledge and creating themselves as practitioners in the context of the transfer of theoretical knowledge [21, 25].

Below I discuss how the practices identified by pedagogy teachers as good practices for teaching about play that are related to the demands of situated condition.

A professional conversation about play is an activity setting that requires student activity, and it is one way of imposing the safeguarding of student agency. However, the crucial elements of safeguarding student agency in this activity setting seem to refer to the following:

- articulating and reflecting on the students' own childhood experiences;

- linking professional concepts with personal experiences;

- referring to current debates about the kindergarten sector and play.

These elements anchor the transfer of theoretical knowledge in the students' own biographical experiences, which safeguards the presence of students as subjects with valuable experiences in the teaching process. The recognition of students' experiences of play is real, and professional conservations build on them further while also linking them to theoretical and professional concepts. This allows students to not only create an understanding of play that is related to their own experiences of play, but also to reflect upon their own childhoods through the concepts presented. Opening up the dialectics between the theory presented and the students' biographical experiences can thereby be seen as the recognition of the students as subjects, the recognition of the students' experiences, and their empowerment to be active agents in their own learning. This happens not only through the activity of talking during teaching hours, but also by inviting in parts of the students' biographies.

Anchoring the conversation about play in the students' biographies is also a way of contextualizing play in sets of cultural practices. After reflecting on their play for a while, students will see that this activity is not isolated in a sociocultural vacuum, but it is always part of broader practices connected either to family life, children's culture, popculture, or the institutionalized context of kindergarten and school. However, on another level, an analogical reference to cultural practices happens in professional conversations about play by referring the subject of play to current debates on it. As citizens and more or less active or passive participants in public discourse, the students hear and read 
about, for example, tensions between the kindergarten teachers defending the position of play [31] and the government expecting more school-learning in the kindergartens [32]. Discussing the theoretical concepts presented during campus-based teaching from the perspective on ongoing debates presents play as a cultural practice of which the students are also a part.

Since the cultural surroundings of personal biographies and current public debate are the natural surroundings of play, the activity setting of the professional conservation also fulfills this aspect of situated cognition.

Another aspect of situated cognition that professional conversations about play address is the level of student development. These conversations address the students' levels of reflection on their own memories and their understanding of the theoretical content that they are assigned to read for classes. They encounter this dialogue with nothing more than their own level of development, and it is the dialogue with others, who have different understandings of the various aspects of play, that can carry them along further in their own understanding of the material $[21,25]$. Thus, the students are agents not only in their own learning, but also in the learning processes of other students.

The other activity settings in which situated conditions are discussed include play activities in which the students experience:

- $\quad$ being outside their comfort-zones;

- letting control slide;

- joining an "as if" situations and laughter.

Thus, play activities directly situate students in play situations or emotional states that are required by play. On the one hand, this provides students with another aspect of being agents in their own learning since it allows them to act in the "as if" frameworks provided. On the other hand, it recognizes the students as subjects who are able to act, experience, and reflect upon activities. However, the core of situated cognition provided by play activities seems to be anchored in providing students with the natural surroundings of play that facilitate play. Experiencing play oneself, being a part of a plot, struggling with conflict, or with continuing play and/or stories are all important experiences that are later integrated into more theoretical reflections in ways that are analogous to students' biographical experiences.

When it comes to other teaching and/or learning activities that stimulate critical reflections about play, they seem to support situated conditions by showing the absolute necessity of independent thinking by underscoring the diversity of meanings and arguments in theoretical discourse on play. Other teaching and/ or learning activities that stimulate critical reflections about play support students' meaning making and students as subjects who are able to tackle issues and position themselves in relation to certain dilemmas and discussions that occur in the theoretical discourse. This is done by identifying play as an interdisciplinary and a definitely unambiguous concept [33], depending on environmental conditions, that is researched from various disciplinary perspectives and, thus, is described variously, for example, as a learning activity, as a way to learn, or as an activity with its own value. Not of lesser importance is permitting students to present autocritical thoughts about professionals who over-romanticize the phenomenon of play, especially those who work within the Nordic education model [14]. All of this contributes to stimulating students' own agency in meaning-making processes that are related to situated conditions.

\section{Summary}

This paper employs the cultural-historical wholeness approach to shed light on campus-based teaching practices about play within the field of kindergarten teacher education in Norway. The perspectives of academic pedagogy teachers were reconstructed empirically and then discussed. Teaching a practice-related subject such as play, which is simultaneously anchored in various cultural practices, is not easy. How balance is to be achieved between theoretical and situated learning is a dilemma facing the academic pedagogy teachers who, in this study, share their experiences of best practices in teaching about the subject of play. The analysis of the results leads to a discussion about the conditions of situated cognition, and various theories on play are presented that are absolutely necessary in professional education. The institutional practices of the following activity settings are highlighted in the paper: a) professional conversations about play; b) play activities; and c) teaching and/or learning activities that stimulate critical reflection. These, in turn, provide the conditions for the following: a) understanding and experiencing play as a cultural practice; b) linking personal biographical experiences with theories; c) positioning oneself within theoretical disagreements and dilemmas. The specific contribution of this study is its description of institutional conditions for situated conditions in campusbased activity settings. This is a phenomenon that requires further exploration, especially in relation to the higher education of professional practitioners.

\section{REFERENCES}

[1] J. Brown, D. Isaacs. The World Café. Shaping Our Future Through Conversations That Matter. Berrett-Koehler, San Francisco. 2005.

[2] P. Mayring. Qualitative Content Analysis. Forum: Qualitative Social Research, Vol. 1, No.2, Art. 20, 2000.

[3] Følgegruppe for barnehagelærerutdanning. Barnehagelærarutdanninga. Meir Samanheng, betre heilskap, klarare profesjonsretting. Rapport frå Følgjegruppa til 
Kunnskapsdepartementet. Rapport nr. 2. Følgegruppe for barnehagelærerutdanning. 2005.

[4] Følgegruppe for barnehagelærerutdanning. Styrker, svakheiter og gjenstridige utfordringar. Rapport nr.5 til Kunnskapsdepartementet. 2017.

[5] M. Hedegaard. Analyzing Children's Learning and Development in Everyday Settings from a CulturalHistorical Wholeness Approach. Mind, Culture, and Activity, Vol. 19, 127-138, 2012.

[6] M. Hedegaard. Tækning viden utdvikling. Aarhus Universitetsforlag, Aarhus. 1995.

[7] B. Kristjánsson. The Making of the Nordic Childhood. In: J. Einarsdottir, J. T. Wagner (Eds.), Nordic Childhoods and Early Education: Philosophy, Research, Policy, and Practice in Denmark, Finland, Iceland, Norway, and Sweden. Information, Greenwich, 13-42, 2006.

[8] A. Sadownik, E. E. Ødegaard. Early Childhood Education and Care in Norway: Cultural Historical Context, New Regulations and Perceived Quality. In: Early Childhood Education in the 21st Century - Volume 1. New York, Routledge. 2018.

[9] I. Pramling Samuelsson, M. Asplund Carlsson. The playing learning child: Towards a pedagogy of early childhood. Scandinavian Journal of Educational Research, Vol. 52, No. 6, 623- 641, 2008.

[10] A. C. Vallberg Roth. Nordisk komparativ analys av riktlinjer för kvalitet och innhåll i förskolan. Nordic Council of Ministers, København. 2013.

[11] Kunnskapsdepartementet. Rammeplan for barnehagen. Innhold og oppgaver. Oslo. Utdanningsdirektoratet. 2006.

[12] Kunnskapsdepartementet. Rammeplan for barnehagens innhold og oppgaver. Oslo. Kunnskapsdepartementet. 2011.

[13] Kunnskapsdepartementet. Rammeplan for barnehagens innhold og oppgaver. Oslo. Kunnskapsdepartementet. 2017.

[14] B. Jensen. A Nordic Approach to Early Childhood Education (ECE) and Socially Endangered Children. European Early Childhood Education Research Journal, Vol. 17, No. 1, 721, 2009. doi:10.1080/135029308026889880.

[15] A. Sadownik. Belonging and participation at stake. Polish migrant children about (mis)recognition of their needs in Norwegian ECECs. European Early Childhood Education Research Journal, Published on-line: 17 October 2018, p.116, 2018. DOI: DOI: 10.1080/1350293X.2018.1533711

[16] T. Grindheim. Children as playing citizens., European Early Childhood Education Research Journal, Vol. 25, No. 4, 624636, 2017. DOI: 10.1080/1350293X.2017.1331076.

[17] T. Grindheim. Beyond uniform reproduction: Exploring children's imaginative play through the lenses of their teacher. Early Childhood, 1-12, 2018. DOI:0.1177/1463949118783384

[18] A. James, C. Jenks, A. Prout. Theorizing Childhood. Polity Press, Cambridge. 1998.

[19] G. Dahlberg, P. Moss, A. Pence. Beyond Quality in Early Childhood. Languages of evaluation. Second edition. Routledge, London and New York. 2007.
[20] J. H. Kallestad, E. Ødegaard. Children's Activities in Norwegian Kindergartens. Part 1: An Overall Picture. Psychology, Vol. 9, No. 4, 72- 82, 2013.

[21] M. Hedegaard. Situated learning and Cognition: Theoretical Learning and Cognition. Mind Culture, and Activity, Vol. 5, No. 2, 114-126, 1998. DOI: 10.1207/s15327884mca0502 5

[22] Ø.F. Standal, E. Jespersen. Peers as Resources for Learning: A Situated Learning Approach to Adapted Physical Activity in Rehabilitation. Adapted Physical Activity Quarterly, Vol. 25, 208-227, 2008 .

[23] J. Lave, E. Wenger. Situated learning. Legitimate Peripheral Participation. Cambridge University Press, New York. 1991.

[24] A. S. Palinscar. Response to Brown, Collins and Duguid's "Situated cognition and the culture of learning": Less charted waters. Educational Researcher, Vol. 18, No. 4, 5-7, 1989.

[25] L. S. Vygotsky, L. S. Mind in Society. The Development of Higher Psychological Processes. Harvard University Press, New York. 1978

[26] M. Boge, G. Markhus, R. Moe, E. E. Ødegaard. Læring gjennom veiledning. Meningskaping i grupper. Fagbokforlaget, Bergen. 2009.

[27] S. Kvale, S. Brinkmann. Det kvalitative forskningsintervju. Gyldendal Norsk Forlag AS, Oslo. 2015.

[28] J. Kitzinger, R. S. Barbour. Developing focus group research: politics, theory and practice. Sage, London. 1999.

[29] A. Tjora. Kvalitative forskningsmetoder i praksis. Gyldendal Akademisk, Oslo. 2010.

[30] L. Cohen, L. Manion, K. Morrison. Research methods in education. Routledge, New York. 2017.

[31] B. Bae. Politikk, lek og læring. Barnehageliv fra mange kanter. Fagbokforlaget, Bergen. 2018.

[32] Kunnskapsdepartementet. Tid for lek og læring. Bedre innhold i barnehagen (Meld. St.19) (2015-2016). 2015.

[33] B. Sutton-Smith. The Ambiguity of Play. Harvard University Press, Cambridge, London. 1997. 